\title{
Carlos S. Alvarado's Contribution to Psi Research in Brazil'
}

\author{
Wellington Zangari \& Fatima Regina Machado \\ University of Sao Paulo
}

Our personal and professional contact with Carlos S. Alvarado began in the 1990s, when a strong personal friendship and professional collaboration were created, extended to the also eminent researcher Nancy L. Zingrone, Alvarado's wife. The contact between us became more and more frequent and provided a deep exchange of ideas and experiences that inspired our work throughout the history of our research group in Brazil, that became the laboratory InterPsi - Laboratory of Psychosocial Studies "Belief, Subjectivity, Culture \& Health," established at the University of São Paulo (USP) the most important public university in the country.

Carlos Alvarado, as well as Nancy Zingrone and Stanley Krippner, were/are instrumental for the development of psi research in Brazil. Regarding specifically Alvarado's contribution, we highlight his studies and writings on different psi research topics, his encouragement to "introduce psi research" into the Brazilian academic environment, and his joint works with Brazilian colleagues; his enthusiasm, personal engagement, and presence in academic-scientific activities in the country were fundamental. His avid interest in knowing how parapsychology was developed and/or perceived in different contexts tied to his ability to read several languages (Portuguese, French, Italian, Spanish, and English) made him a great connoisseur of different "psi cultures." Therefore, he was aware of how problematic are language barriers in parapsychology (Alvarado, 1989) and discussed how parapsychology's regionality circumscribed it to the Euro-American axis, local biases in other contexts, and suggested strategies to reduce them (e.g., Machado \& Alvarado, 1997). He understood remarkably well how parapsychology was developed in Brazil, its different perspectives and problems derived from them, which allowed him to perceive what would be necessary to develop

\footnotetext{
1 Address correspondence to: InterPsi - Laboratory of Psychosocial Studies Belief, Subjectivity, Culture \& Health, Institute of Psychology - University of São Paulo, Wellington Zangari, Ph. D., w.z@usp.br or Fatima Regina Machado,Ph. D., fatimaregina@usp.br
} 
psi research in each context. Thus, Alvarado helped us to define strategic actions to develop psi research and introduce it into the Brazilian academic environment.

Alvarado was fundamental for education in psi research in our country. In 1995, 2002 and 2011 he carried out academic-scientific activities (courses, lectures and research meetings) in the country, besides having been interviewed by the local media talking about psi research to the general public. In 1995, Alvarado taught a course on consciousness studies, updating information on parapsychological studies, at Anhembi Morumbi College (now Anhembi Morumbi University). In 2002, he participated of the First InterPsi Seminar "Intuitive Communication: Theoretical and Clinical Aspects" at the Pontifical Catholic University of São Paulo. In 2011, besides attending the Parapsychological Association Convention held in Curitiba, in the South of Brazil, Alvarado and Zingrone (occasion when she taught a course on the psychological study of anomalous experiences at USP) also participated of research meetings with InterPsi members, as they had also done in 1995 and 2002. The activities developed by Alvarado in the country contributed to broaden general knowledge on psi research and emphasized the importance of empirical research and scientific production in the area.

Alvarado was also instrumental in encouraging joint works among Brazilian colleagues. He himself co-authored papers and chapters with Brazilian colleagues, mainly on dissociation and historical and/or methodological topics (Alvarado et al., 2007; Alvarado et al., 1997; Alvarado et al., 1998; Alvarado et al., 2014; Lange et al., 2018; Maraldi et al., 2016; Maraldi \& Alvarado, 2018; Moreira-Almeida et al., 2007). Alvarado was always ready and open to discuss research projects and offer methodological suggestions. He felt happy especially in discussing and indicating specialized literature to base theoretically research projects and papers, as he did with USP master and doctorate candidates. More recently Alvarado (2020) presented the historical importance of psychical research studies for psychology in an open webinar organized by InterPsi-USP.

We also underline Alvarado's importance to the development of psi research in Latin America, with repercussions for the expansion of the field in Brazil. In the occasion of the PA Convention held in 1995 in Durham, NC, PA members who were researchers in Portugal and Latin American countries founded the Associación Iberoamericana de Parapsicologia (AIPA), whose aim was to discuss strategies to develop parapsychology according to specificities of the field in each geographic and cultural region. Besides being instrumental in AIPA'S foundation, Alvarado was unanimously elected its president. In partnership with Nancy Zingrone, one of the main AIPA's activities he carried out was the organization and teaching of a psi research program, whose aim 
was to spread basic parapsychological knowledge, reducing language and conceptual barriers. About 10 regional groups (three of them in Brazil) took part in that program, which contributed to collective growth, especially in methodological terms. As a consequence, our and other research groups reinforced their interest in empirical research and bringing psi research into academy. In this sense, AIPA, chaired by Alvarado, was a watershed for psi research in our context.

In addition to being a great friend of ours, Alvarado was one of the greatest inspirers for psi research in Brazil. He encouraged us to take psi research into academy and rejoiced with each new research, dissertation, or thesis in the area carried out in our country. It is not possible to think of the development of psi research in Brazil without remembering and referring to his constant and enthusiastic presence. We are eternally grateful to him and remain inspired by his efforts and support.

\section{References}

Alvarado C. S. (2020, April 21). I Webinar InterPsi: "Pesquisa psíquica e psicologia: A importância da perspectiva histórica" [First InterPsi Webinar: Psychical Research and Psychology: The importance of historical perspective.] [Webinar] InterPsi - Laboratório de Estudos Psicossociais "Crença, Subjetividade, Cultura \& Saúde". https://www.youtube.com/watch?v=BNqbTcXqelY\&t $=4864 \mathrm{~s}$

Alvarado, C. S. (1989). The language barrier in parapsychology. Journal of Parapsychology, $53(2), 125-139$.

Alvarado, C. S., Machado, F. R., \& Zingrone, N. L. (1997). Métodos de investigación en parapsicología: Parte I [Research Methods in Parapsychology: Part 1]. Boletim AIPA, 1(3), 13-16.

Alvarado, C. S., Machado, F. R., \& Zingrone, N. L. (1998). Métodos de investigación en parapsicología. Parte II [Research Methods in Parapsychology: Part 2]. Boletim AIPA, 2(1), 9-12.

Alvarado, C. S., Maraldi, E. O., Machado, F. R., \& Zangari, W. (2014). Théodore Flournoy's contributions to Psychical Research. Journal of the Society for Psychical Research, 78(916), 149-168.

Alvarado, C. S., Machado, F. R., Zangari, W., \& Zingrone, N. L. (2007). Perspectivas históricas da influência da mediunidade na construção de ideias psicológicas e psiquiátricas [Historical perspectives of the influence of mediumship in the construction of psychological and psychiatric ideas]. Revista de Psiquiatria Clínica, 34, 42-53. https://doi.org/10.1590/s010160832007000700007

Lange, R., Maraldi, E. D. O., Zangari, W., Corredato, V., Machado, F. R., \& Alvarado, C. S. (2018). A cross-cultural validation of the Revised Transliminality Scale in Brazil. Psychology of Consciousness: Theory, Research, and Practice, 5(4), 414-424. https://doi.org/10.1037/cns0000161 Machado, F. R., \& Alvarado, C. S. (1997) Sobre o provincianismo em Parapsicologia [On provin- 
cialism in parapsychology]. Anais do I Congresso Internacional e Brasileiro de Parapsicologia (pp. 75-88). Instituto Pernambucano de Pesquisas Psicobiofísicas.

Maraldi, E. O, \& Alvarado, C. S. (2018). Final chapter, From India to the Planet Mars: A Study of a Case of Somnambulism with Glossolalia, by Théodore Flournoy (1900). History of Psychiatry, 29(1), 110-125. https://doi.org/10.1177/0957154X17734782

Maraldi, E. O., Alvarado, C., Zangari, W., \& Machado, F. R. (2016). Dissociação, crença e criatividade: uma introdução ao pensamento de Théodore Flournoy [Dissociation, belief and creativity: an introduction to the thoughts of Théodore Flournoy]. Memorandum: Memória e História em Psicologia, 30, 12-37.

Moreira-Almeida, A., Alvarado, C. S., \& Zangari, W. (2007) Transtornos dissociativos (ou conversivos) [Dissociative (or conversion) disorders]. In M. R. Louzã Neto \& H. Elkis. (Eds.). Psiquiatria básica [Basic psychiatry] (2a ed., pp. 285-297). Artmed. 